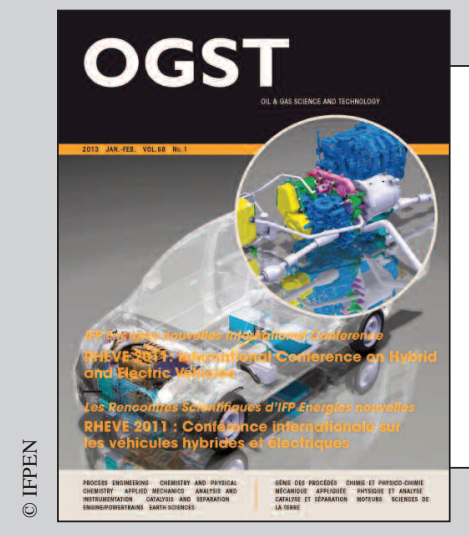

Dossier

This paper is a part of the hereunder thematic dossier published in OGST Journal, Vol. 68, No. 1, pp. 3-178 and available online here

Cet article fait partie du dossier thématique ci-dessous publié dans la revue OGST, Vol. 68, n 1 , pp. 3-178 et téléchargeable ici

DOSSIER Edited by/Sous la direction de : A. Sciarretta, F. Badin et J. Bernard RHEVE 2011 : International Conference on Hybrid and Electric Vehicles RHEVE 2011 : Conférence internationale sur les véhicules hybrides et électriques

Oil \& Gas Science and Technology - Rev. IFP Energies nouvelles, Vol. 68 (2013), No. 1, pp. 3-178

Copyright (C) 2013, IFP Energies nouvelles

\section{$3>$ Editorial}

$13>$ Analysis and Experimental Implementation of a Heuristic Strategy for Onboard Energy Management of a Hybrid Solar Vehicle

Analyse et expérimentation d'une stratégie heuristique pour la gestion d'énergie à bord d'un véhicule hybride solaire

G. Coraggio, C. Pisanti, G. Rizzo and M. Sorrentino

23 > Open Issues in Supervisory Control of Hybrid Electric Vehicles: A Unified Approach Using Optimal Control Methods

Questions ouvertes sur la supervision énergétique des véhicules hybrides électriques : une approche unifiée par la théorie de la commande optimale

L. Serrao, A. Sciarretta, 0. Grondin, A. Chasse, Y. Creff, D. Di Domenico, P. Pognant-Gros, C. Querel and L. Thibault

35 > Optimization of Hybrid Power Trains by Mechanistic System Simulations

Optimisation de groupes motopropulseurs électriques hybrides par simulation du système mécanique

T. Katrašnik and J.C. Wurzenberger

51 > A Phenomenological Heat Transfer Model of SI Engines - Application to the Simulation of a Full-Hybrid Vehicle

Un modèle phénoménologique de transfert thermique au sein de moteurs à allumage commandé - Application à la simulation d'un véhicule full-hybride

R. Dubouil, J.-F. Hetet and A. Maiboom

$65>$ Battery Electric Vehicle (BEV) or Range Extended Electric Vehicle (REEV)? - Deciding Between Different Alternative Drives Based on Measured Individual Operational Profiles

Véhicule électrique à batteries (BEV) ou véhicule électrique à prolongateur d'autonomie (REEV) ? - Choisir entre différents entrânements alternatifs sur la base de profils opérationnels individuels mesurés

S. Marker, B. Rippel, P. Waldowski, A. Schulz and V. Schindler

$79>$ Assessment by Simulation of Benefi ts of New HEV Powertrain Configurations

Évaluation par simulation des bénéfi ces de nouvelles chaînes de traction hybrides

N. Kim and A. Rousseau
95 > Dual Mode Vehicle with In-Wheel Motor: Regenerative Braking Optimization

Véhicule bi-mode avec moteurs roues : optimisation du freinage récupératif

G. Le Solliec, A. Chasse, J. Van-Frank and D. Walser

109 > Engine Downsizing and Electric Hybridization Under Consideration of Cost and Drivability

Réduction de taille moteur et hybridation électrique avec considérations de coût et de performance de conduite

S. Ebbesen, P. Elbert and L. Guzzella

117 > Representative Midwestern US Cycles: Synthesis and Applications Cycles représentatifs du Middle West américain : synthèse et applications

T.-K. Lee and Z.S. Filipi

127 > A Review of Approaches for the Design of Li-lon BMS Estimation Functions

Revue de différentes approches pour l'estimation de l'état de charge de batteries Li-ion

D. Di Domenico, Y. Creff, E. Prada, P. Duchêne, J. Bernard and V. Sauvant-Moynot

137 > Experimental Assessment of Battery Cycle Life Within the SIMSTOCK Research Program

Évaluation expérimentale de la durée de vie de la batterie dans le programme de recherche SIMSTOCK

P. Gyan, P. Aubret, J. Hafsaoui, F. Sellier, S. Bourlot, S. Zinola and F. Badin

$149>$ Smart Battery Thermal Management for PHEV Efficiency Une gestion avancée de la thermique de la batterie basse tension de traction pour optimiser l'efficacité d'un véhicule hybride électrique rechargeable

L. Lefebvre

$165>$ Parameterization and Observability Analysis of Scalable Battery Clusters for Onboard Thermal Management

Paramétrage et analyse d'observabilité de clusters de batteries de taille variable pour une gestion thermique embarquée

Xinfan Lin, Huan Fu, Hector E. Perez, Jason B. Siege, Anna G. Stefanopoulou, Yi Ding and Matthew P. Castanier 


\title{
Smart Battery Thermal Management for PHEV Efficiency
}

\author{
L. Lefebvre \\ PSA Peugeot Citroën, Direction Recherche et Développement, 18 rue des Fauvelles, 92250 La Garenne-Colombes - France \\ e-mail: ludovic.lefebvre@mpsa.com
}

\begin{abstract}
Résumé - Une gestion avancée de la thermique de la batterie basse tension de traction pour optimiser l'efficacité d'un véhicule hybride électrique rechargeable - L'atteinte des performances et des prestations requises d'un véhicule électrique ou hybride électrique rechargeable nécessite un thermomanagement intelligent de la batterie basse tension de traction. Ce thermomanagement est incontournable pour respecter dans le même temps la disponibilité d'énergie de traction électrique et la durabilité de la batterie. La conception du système de gestion thermique de la batterie basse tension doit donc prendre en compte les exigences requises de la chaîne de traction et du véhicule, la conception et l'architecture du pack batterie, les contraintes d'environnement, au moindre coût et au moindre poids, etc., tout en optimisant les compromis entre ces paramètres souvent antagonistes. Le processus de conception du thermomanagement de la batterie basse tension de traction fait l'objet de la première partie de cet article. Ce processus sera illustré par deux exemples, l'un mettant en œuvre l'air en provenance de l'habitacle du véhicule et l'autre, par un refroidissement direct via le circuit de réfrigération du véhicule. Pour une application concrète, le processus de décision doit intégrer l'ensemble des modes de thermomanagement étudiés dans ce contexte et les différents paramètres et exigences pris en compte en tant que données d'entrée. La seconde partie de l'article présente un modèle de simulation thermoélectrique simplifié de la batterie basse tension de traction. Quelques résultats de calculs seront présentés à titre d'exemples dans deux perspectives différentes, d'une part, le dimensionnement thermique du système de thermomanagement, et d'autre part, l'optimisation du bilan énergétique du véhicule. Par ailleurs, ce modèle de simulation simplifié a également permis d'identifier et d'évaluer plusieurs stratégies pertinentes de gestion thermique de la batterie. Ces stratégies visent à améliorer l'efficacité et la performance du véhicule tout en ménageant la durée de vie de la batterie. La troisième partie présente certaines de ces stratégies. Parmi celles-ci, le post-refroidissement et le préconditionnement thermique de la batterie basse tension de traction, en préchauffage par conditions froides et en refroidissement. Ces stratégies ont montré une augmentation de l'énergie et de la puissance électrique alors disponibles. La disponibilité et l'autonomie de la mobilité tout électrique s'en trouvent d'autant améliorées. Le post-refroidissement et le préconditionnement thermique de la batterie basse tension de traction permettent aussi un gain sensible sur la durabilité de la batterie basse tension. D'autres stratégies prometteuses optimisant le compromis entre performances du véhicule et durabilité de la batterie de traction sont encore en cours d'investigation.
\end{abstract}

\footnotetext{
Abstract - Smart Battery Thermal Management for PHEV Efficiency - A smart battery thermal management is crucial for vehicle performances and battery lifetime targets achievements when electric and plug-in hybrid electric vehicles are concerned. The thermal system needs to be designed and tuned in accordance and compromises with powertrain and vehicle requirements, battery pack architecture, environmental constraints, costs, weight, etc., in a process that will be described in the first part of this paper. Among the portfolio of battery thermal management technologies, these items will be illustrated
} 
by two examples: thermal management by cabin air and by refrigerant in a direct cooling, enlightening a decision process. A simplified battery thermo-electric simulation model, which the second part of our work focuses on, has been built, first for both thermal and energetic balance dimensioning of the battery thermal management system. Examples are given on these two perspectives. That simplified simulation model has also identified some promising thermal management strategies for improving vehicle efficiency and performances and battery lifetime. That is the task of the last part of this paper. Battery heating has shown opportunities for improving energy and power availability at cold conditions and, thus, electric drive availability and autonomy. Post-cooling the battery at the end of a journey and its pre-conditioning before the following journey, not only improve vehicle efficiency, electric drive availability and autonomy, but also enhance battery lifetime and compromises with cabin thermal comfort. Others promising strategies optimizing the relation between vehicle performances and battery lifetime are still under investigations.

\section{INTRODUCTION}

As global warming has become one of the most important concerns of the 21st century, governments provide incentives and legislation to entice Original Equipment Manufacturers (OEM) to offer cleaner and/or alternative powertrains. Hence, the automotive industry is just going through one of its major improvements with the development of commercially and economically viable Electric Vehicle (EV) and Hybrid Electric Vehicles (HEV), with depletion of world fuel reserves and contribution to pollutant emission levels as main drivers. For such EV and HEV with electrified powertrains, the Low Voltage ${ }^{1}$ (LV) Electrical Energy Storage System (EESS) is the key component, as far as vehicle selling price and residual value, $R \& D$ costs, weight, layout and packaging, efficiency, performances and driving range, safety, reliability, servicing, warranty, recycling, etc., are concerned. Due to their different properties (especially energy and power densities, high number of allowable charging and discharging cycles, no memory effect - no reduction of the apparent discharge capacity when the battery is repetitively discharged incompletely and then recharged), lithium-ion (Li-ion) accumulators are suitable for meeting all of these challenges and will be used as the EESS in most of future EV and HEV. But such Li-ion batteries, due to the high thermal sensitivity of their electrochemistry, also require especially high attention on their temperature management.

\footnotetext{
1 Table 1 below defines the high, low and extra-low voltage ranges, in compliance with the International Electrotechnical Commission (IEC), where $V_{r m s}$ means root mean square volts:
}

TABLE 1

Definition of IEC voltage ranges

\begin{tabular}{c|c|c}
\hline IEC voltage range & Alternating current (AC) & Direct current (DC) \\
\hline High voltage & $>1000 V_{r m s}$ & $>1500 \mathrm{~V}$ \\
\hline Low voltage & $25-1000 V_{r m s}$ & $60-1500 \mathrm{~V}$ \\
\hline Extra-low voltage & $<25 V_{r m s}$ & $<60 \mathrm{~V}$ \\
\hline
\end{tabular}

According to Arrhenius law, the rate at which a chemical reaction proceeds increases in an exponential manner as temperature rises. Consequently, the higher the temperature, the more instantaneous electric power can be extracted and the more mobile the electrons, reducing cell's impedance and increasing its capacity. However, a too high temperature of the cells may initiate unwanted or irreversible chemical reactions and could result in cells swelling, leading to mechanical distortions resulting in short or open circuits, thermal runaway (as a consequence of exothermic chemical reactions, ones after the others, with subsequent property hazard and safety issues), electrolyte breakdown (even in form of Solid Electrolyte Interface (SEI) layer), irreversible capacity loss and reduction in lifetime.

On the contrary, always according to Arrhenius law, at too low temperature performance the rate of the chemical reaction is reduced. In addition, electrolyte may freeze. Consequences are battery performance deterioration, capacity loss (in some cases irreversibly) and lifetime reduction.

Consequently, a relevant Li-ion battery thermal management is required to keep it within a limited operating temperature range to achieve performance and lifetime optimization, needing in most cases both heating and cooling.

Depending on:

- the kind of HEV (and especially Plug-in HEV (PHEV)) and EV;

- vehicle targets in terms of driving profile, performances, efficiency and driving range;

- technologies involved (type of cells, voltage range, electric engines, etc.);

- packaging and layout;

- etc.

The most relevant cooling methods (type of coolant):

- ambient or cabin air;

- ultra-low $\left(\approx 20^{\circ} \mathrm{C}\right)$ or low $\left(<50\right.$ to $\left.70^{\circ} \mathrm{C}\right)$ temperature water-glycol coolant;

- refrigerant (biphasic fluid) from the refrigerant circuit of the A/C (air conditioning) system;

- other innovative and/or less usual coolants; 
- benefits and drawbacks of each above cooling method and their combination taken into account.

And architectures have to be chosen, keeping in mind the complete vehicle system, considering interactions between vehicle and powertrain subsystems.

This paper is divided into three parts. The first part describes the process to design a LV battery thermal management system. The second part introduces a battery simulation model with both thermal and electric models linked together. To finish with, some strategies for improving vehicle efficiency and battery lifetime will be introduced.

\section{BATTERY THERMAL MANAGEMENT DESIGN PROCESS}

The fundamental requirement of a LV Li-ion battery thermal management system is to guarantee the most relevant temperature at the cell level.

\subsection{Design Process}

\subsubsection{External Requirements and Constraints}

To do so, the thermal management of a Li-ion battery is submitted to requirements, constraints and interfaces coming from both vehicle and powertrain:

- efficiency, pure electric driving range, performance everlastingness, Zero Emission Vehicle (ZEV) mode availability, lifetime, etc.;

- passenger comfort: thermal, acoustics, etc.;

- thermal architectures: fluids already involved, possible impacts on Heating Ventilating Air Conditioning (HVAC) and cooling systems, etc.;

- layout and packaging;

- plug-in recharging (especially fast charging);

- safety (passenger, powertrain) and venting;

- costs and mass targets.

Additional constraints are:

- climate: journey areas, temperature, humidity, seasons, etc.;

- storage conditions.

And regulations: safety (venting, etc.), recycling, etc.

\subsubsection{Battery Internal Requirements and Constraints}

This section introduced battery thermal management, at both cells and internal cooling system levels.

\subsubsection{Cells}

Of course the battery itself requires a special care to be paid to its thermal management, first of all depending on the type of cells, the technologies that are involved in the cells and the resulting thermal constraints. For a subsequent energetic approach, efficiency, capacity and performances are the major parameters that have to be dealt with. Finally, safety and costs must also be addressed.

Type of Cells

Cylindrical, pouch and hard case prismatic are the currently used cell types for Li-ion batteries. From a cooling point of view, some geometric drawbacks can be enlightened, as far as heat transfer from the interior to the cell's external surface in close contact with the coolant fluid is concerned: surfaceto-volume ratio and thermal contact especially.

\section{Technologies Involved}

Apart from the type of electrochemistry (among the Li-ion family) that might introduce some slight specific requirements or adjustments on the thermal management strategies, let's keep especially in mind all physical characteristics involved in the heat transfer process: weight, density, sizes (in particular, thermal contact area between cells and coolant or internal heat exchanger), quality of contact area (flatness, thermal contact spots, roughness), specific thermal capacity, heat conductivity in the three directions of the cell (axial, radial, perpendicular to cell surfaces), heat transfer coefficient of cell surfaces.

\section{Thermal Constraints}

Maximal temperature before overload, temperature range to maximise efficiency, maximal (ageing and required lifetime taken into account) and minimal (considering full electric power availability) operation temperatures, maximal and minimal storage temperatures, are the main parameters to be monitored. Due to the high thermal sensitivity of the electrochemistry of such Li-ion cells, maximal temperature gradients within one cell and between all cells of a battery module also have to be taken into account.

\section{Efficiency and Performances}

Performances and efficiencies (electric, thermodynamic, faradaic, etc.) are managed as functions of battery and ambient temperatures, State of Charge (SOC), supplied current (in charge and discharge mode) and ageing.

\section{Capacity}

Cells capacity is managed as a function of cells and ambient temperatures, availability in cold conditions and derating in hot conditions taken into account.

\section{Safety}

Failure effects (electric, integrity, overheat) and thermal overload (venting, temperature, gases emitted) are the first safety issues. Fire (flame resistance, burning, burst) can also occur and is to be taken into account.

\section{Costs}

The costs analysis involves cells (number, technologies, production maturity, etc.) consideration and adaptation for cells assembly in module (cooling topics included). 


\subsubsection{Internal Cooling System}

The internal cooling system must tackle thermal transfer between cells and coolant fluid. To do so, a cooling method is to be chosen.

\section{Cooling Methods: Drawbacks and Benefits}

A first cooling method presents no direct thermal contact, through air cooling (preferably with air from the cabin). In such a case, each cell is cooled through its free surfaces by air flowing around. This relatively simple cooling method involves quite simple interfaces with the cooling system. However, inlet and outlet air ducts and air channels inside the battery pack between the cells introduce impacts on packaging and layout. In addition, electric and acoustics constraints on the blower, safety concerns, compromises between cabin thermal and acoustics comfort and battery cooling, low cooling overall performance and heterogeneity in air flow and consequently cell temperature distribution are drawbacks and challenges to overcome.

On the contrary, cooling methods (involving refrigerant and/or water-glycol cooling) through thermal contact with cells and heat conduction (with or without heat conducting elements between cells) have revealed better efficiency and packaging. However, challenges in those cases focus on a good thermal contact and on a not too complex interface with the cooling system.

The "refrigerant cooling" method, with the evaporator inside the battery pack in thermal contact with cells, in parallel with the cabin evaporator, provide a very compact battery cooling system. The refrigerant evaporates on the channels provided in the battery cooler and thus absorbs cells heat losses. High cooling capacity is reachable, with a refrigerant temperature level in the battery loop of around $0^{\circ} \mathrm{C}$ to $15^{\circ} \mathrm{C}$. In addition to the thermal contact challenge already mentioned above, an other constraint on the design of the battery cooler has to be taken into account: providing a homogeneous temperature distribution over the whole cooler surface in contact with cells. However, both cabin and battery cooling needs, with their dedicated evaporators on the same refrigerant circuit, have to be matched to each other, through a precise $\mathrm{A} / \mathrm{C}$ system management (A/C compressor, especially variable-speed electrically driven and expansion valves, compressor lubricant trapping). In addition, battery cooling could not operate at temperatures below $-5^{\circ} \mathrm{C}$ to $-10^{\circ} \mathrm{C}$ (even if this is usually acceptable in practice) and no battery heating is possible without additional devices (dedicated battery heater or operating the refrigerant circuit in heat pump mode).

The "coolant cooling" method affords more flexibility on battery pack package and layout, but requires a dedicated loop, separated from the rest of the cooling circuit, with an additional heat exchanger (chiller: water-glycol/refrigerant evaporator), additional coolant and refrigerant tubes, in most cases a water-pump and a valve. Such a design can provide acceptable efficiency of the whole battery cooling system by avoiding unnecessary electric $\mathrm{A} / \mathrm{C}$ compressor operations. Medium to high cooling capacity is reachable, with a coolant temperature level in the battery loop between $10^{\circ} \mathrm{C}$ and $30^{\circ} \mathrm{C}$, depending on cells thermal properties and management strategies. As far as battery heating is concerned, the coolant cooling method offers more practical and different possibilities than the refrigerant's one, using heat lost in the cooling circuits of the Internal Combustion Engine (ICE) or of the other electric components (electric motors and their inverters, power electronics unit, etc.) or through fuel and even electric heaters.

An other promising cooling method, not commonly used nowadays is "conductor cooling" that consists in cooling the core of the cell directly where the heat is generated, through the electrodes and no more through the cell's external surfaces, as good electrical conductors are also good heat conductors. Heat losses are then transferred to a heat sink where either refrigerant or water-glycol coolant releases them into the ambient.

\section{Other Thermal Properties}

- thermal contact characterization: contact pressure, surface characteristics (flatness, thermal contact spots, roughness);

- heat transfer coefficients, all thermal resistances and capacities involved from the jelly roll (cell core) to the coolant fluid, thermal gradients, etc.

The internal cooling system must also take into account the whole heat transfer from the coolant fluid to the outside and their interfaces (flow, tightness, connections, etc.), all of this linked to the mechanical and electrical architectures of the battery pack and modules.

\subsubsection{Optimization Process}

Li-ion battery thermal management system optimization is based on identification of customer representative mission profiles and use-cycles on a powertrain and vehicle energetic balance approach. These cycles and profiles have to be, on a first hand, severe enough for dimensioning the battery cooling system and challenging its limits and on the other, as close as possible to customer usual use-cases for dimensioning the energetic consumption of the cooling system. Thermal losses to be evacuated have to be determined on each type of situation (thermal dimensioning and energetic balance points of view).

To do so, a coupled electrochemical and thermal model is needed, the electrochemical part of the model, not addressed in this paper, necessary in order to understand and forecast chemical reactions (especially their kinetics) and heat release inside a cell.

\subsubsection{Heat Generation}

Heat generation inside Li-ion batteries results from four phenomena [1-3]:

- irreversible resistive heating (Joule heating), due to current flows through the internal resistance, causing a deviation of the cell potential from its equilibrium potential; 
- reversible entropic heating;

- heat from chemical reactions, involving chemical reaction enthalpies;

- heat from concentration gradients, involving concentration and partial molar enthalpy of species in their different phases.

Consequently, heat generation from cell is given by Equation (1):

$$
\begin{aligned}
& Q_{\text {cell }}=I\left(V-V_{o c v}\right)+I T \frac{\partial V_{o c v}}{\partial T} \\
& +\sum_{k} \Delta H_{k} r_{k}+\int \sum_{j} \sum_{i}\left(\overline{H_{i j}}-\overline{H_{i j}^{a v g}}\right) \frac{\partial c_{i j}}{\partial t} d v
\end{aligned}
$$

where:

- the first term is Joule heating, where $I$ is the current of the cell (obtained through current density, determined by electrochemical kinetics), $V$ is the cell potential and $V_{o c v}$ is the volume averaged open circuit potential;

- the second term is the reversible entropic heat, where $T$ is the temperature of the cell; it is positive in case of discharge, negative for charge and nil in case of current pulse;

- the third term is the heat from chemical reactions, where $\Delta H_{k}$ is the reaction enthalpy for each chemical reaction $k$ and $r_{k}$ is the rate of the reaction $k$;

- the fourth term is the heat of mixing due to the generation and relaxation of concentration gradients, where $c_{i j}$ is the concentration of species $i$ in phase $j, d v$ is the differential volume element, $\overline{H_{i j}}$ is the partial molar enthalpy of species $i$ in phase $j$ and $\overline{H_{i j}^{a v g}}$ the averaged partial molar enthalpy of species $i$ in phase $j$.

All of the terms required in Equation (1) are determined by the electrochemical model simulating the thermal electrochemical behaviour of the cell. The sensitivity of parameters to cell temperature is estimated through Arrhenius-type relations.

In practice, for typical driving cycle with repeated charges and discharges at relatively fixed SOC, the second term is negligible, considering Joule heating and the third and fourth terms can usually be ignored in most cases. However, for continuous charge or discharge cases, Joule heating and reversible entropic heating have to be taken into equal account $[1,4]$.

\subsubsection{Energy Balance and Heat Conduction}

Heat transfers inside Li-ion cell and battery are governed $[1,2,5]$ by Equation $(2)$ :

$$
\frac{\partial\left(\rho C_{p} T\right)}{\partial t}=\nabla \cdot(\lambda \nabla T)+Q_{\text {cell }}
$$

where $\rho$ is density, $C_{p}$ is heat capacity, $\lambda$ is heat conductivity (generally anisotropic due to the different materials involved) and $Q_{\text {cell }}$ is given by Equation (1).

Consequently, a map of internal cell temperatures and thermal gradients inside the battery pack is established, that accounts for all thermal and physical properties (heat transfers by conduction, convection and radiation, heat transfer coefficients, thermal resistances and capacities, thermal contact area, each kind of cooling method considered). The evolutions of these parameters are kept under close supervision all along the development stage.

\subsubsection{Overall System Approach}

Finally, by comparison between Li-ion battery thermal criteria and the design limits of each cooling technology, the most appropriate cooling method and architecture is determined through a complete vehicle system and subsystems approach, considering especially interactions between vehicle and powertrain subsystems, dealing in particular with the battery inner cooling architecture and in compromises between costs, layout and packaging, overall efficiency, feasibility, performances and driving range, safety and reliability.

Despite of all these considerations, in case of difficulties in keeping the battery temperature under control before its thermal derating, it is as a last resort furthermore possible to reduce vehicle and powertrain performances as the difficulty to cool the battery increases, in an acceptable and progressive manner by limiting step by step the vehicle and powertrain attributes that can be (for example: boost, then driveability improvement functions, then energy recovery, then etc.) in trade-off with battery lifetime.

\subsection{Functional Parameters}

Hereafter are introduced the main functional parameters of a battery thermal management system.

\subsubsection{Cell Temperature Range}

The schematic diagram (see App. 1) represents the electric power available (and, so, available performances and efficiency) as a function of average battery temperature. This cell temperature range also takes thermal ageing into account.

An ideal temperature range is defined, for example $\left[20^{\circ} \mathrm{C}\right.$ $\left.40^{\circ} \mathrm{C}\right]$ : thermal management has to be designed to regulate the temperature of the Li-ion battery in this range as much time as possible, in a compromise between efficiency and thermal ageing. Below this ideal temperature range, less electric power is available. See also the possible consequences mentioned in the Introduction section.

To be above this ideal temperature range must be considered as very exceptional incursions to be avoided as much as possible due to dramatic thermal ageing acceleration. If battery temperature goes up, available electric power is reduced through electronic derating managed by the Battery Management System (BMS) for self-protection reasons, up to a limit (for example $60^{\circ} \mathrm{C}$, this value can be even higher or lower depending on the type of chemistry involved) where battery self-protection cuts off. 


\subsubsection{Thermal and Electrical Models}

Those models (cells and internal cooler included) deals especially with:

- internal resistances (cells and connections, busbars, etc.) maps as a function of temperature, SOC, pulse time, ageing, in charge and in discharge modes;

- thermal resistances between constituents in contact, thermal capacities of each component, heat transfer coefficients, heat capacities;

- heat transfer areas between constituents, coolant fluid and surroundings (underbody environment, etc.);

- for internal cooler design purpose, maximal thermal gradients within cell and between cells.

\subsubsection{Temperature Sensors}

Those sensors manage the overall thermal system and its derating modes. Internal (cell) temperature sensors have to be provided at relevant locations of each component. Coolant fluid (air, water-glycol, refrigerant) temperature sensors have to be provided at the inlet and/or at the outlet (depending of the kind of cooling method) of the cooler and/or of the cooling circuit. For each kind of temperature sensors: accuracy, resolution and range to be specified.

\subsubsection{Interfaces with the Cooling Circuit}

The additional parameters below also have to be taken into account:

- kind of cooling fluid: air, water-glycol, refrigerant, other;

- coolant flow to be provided and pressure drop curves as a function of coolant flow and temperature;

- nozzles and other organic interfaces.

\subsection{Examples}

This section illustrates the process to design LV battery thermal management by two concrete examples: first by cabin air and then by refrigerant in a direct cooling. In a third part, will be introduced a decision process among the portfolio of thermal management technologies, applied on a particular PHEV project.

\subsubsection{Thermo-Acoustics Design Process of a Battery Thermal Management by Cabin Air}

In a first step, the cooling air flow target is determined, considering the target operating temperature of the battery and per cell or at the whole battery scale through an extrapolation to cells number:

- the heat transfer coefficient between cooling air and cells, as a function of air flow, air temperature at the inlet of the battery pack and cell or battery temperature target;
- the heat losses or thermal power to be evacuated on severe customer cycles.

This first step allows to roughly determine cooling requirements (air flow, thermal gradients between cooling air and cells).

Taking into account the air pressure drop in the battery, depending on its internal architecture, inlet and outlet locations, these cooling requirements are confirmed after an optimization stage (global air flow value, air flow distribution and homogenization, battery pressure drop optimization, aeraulic stratagems, etc.).

The second step consists in tackling air ducts and layout influences. Indeed, air ducts and air fan also have their own influence in a given layout and packaging. The resultant air flow is optimized considering air ducts pressure drops, air inlet and outlet locations, air fan characteristics (air flow, acoustics, electric consumption, etc.), layout and packaging of the whole cooling system. This process may lead to an optimization of air ducts pressure drop and shape, air fan requirements and the whole cooling architecture.

Vehicle and ICE speeds, cabin temperature and acoustics limitations for cabin comfort, with and without $\mathrm{A} / \mathrm{C}$ system, closed or open car windows, driving modes (pure electric, hybrid, etc.), etc., finally introduce their own influence on battery availability, in a compromise with targeted performances, derating and ageing.

\subsubsection{Battery Thermal Management by Refrigerant}

Appendix 2 represents a scheme of an architecture for battery direct cooling through refrigerant. Here is shown a scheme of a refrigerant circuit with two loops in parallel: the first one classically feeds the cabin evaporator and the other one the battery cooler. Each of these two loops is classically managed by an expansion valve and preferably by an additional on/off valve, in order to deal with interactions between the two loops (refrigerant hoses layout, $\mathrm{A} / \mathrm{C}$ compressor lubricant trapping, etc.) and the two cooling needs (cabin air and battery). As a consequence, battery thermal management and cabin thermal comfort are coupled and an acceptable compromise will have to be found for the tuning of these functions.

Are given as inputs of the design process, to be optimized:

- front end cooling module characteristics, especially air-side pressure drops, air flow through heat exchangers, air fan aeraulic and electric requirements;

- customer mission profiles and use cases: ambient temperature, vehicle speed, ICE and electric engines torques and speeds, voltages involved, cabin thermal comfort, whether the $\mathrm{A} / \mathrm{C}$ system is operating or not, driving modes (pure electric, hybrid, etc.), etc.;

- cells thermal constraints: thermal losses, target and minimal/ maximal operating temperatures (including derating at hot and cold conditions), ageing, thermal gradients, etc.; 
- battery internal cooling architecture: heat transfer coefficients from cell core to cooler, all thermal resistances and capacities included, thermal contact area, temperature distribution at the outer surface of the internal battery cooler, etc.;

- environment: ambient, layout, etc.

Outputs of such a design process are:

- requirements on the cooling components:

- first on the battery cooler: heat to be evacuated, technology (roll bond cooling plate, flat tubes, etc.), homogeneous temperature distribution, heat transfer coefficients, refrigerant-side pressure drop, etc.;

- but also on $\mathrm{A} / \mathrm{C}$ compressor, condenser, cooling fan (especially air flow provided and electric consumption), expansion and on/off valves and if needed extra cooling devices;

- and thermal management control strategies, handling for example:

- battery warm-up especially at cold ambient temperatures;

- interactions between the two refrigerant loops, considering cabin thermal comfort and $\mathrm{A} / \mathrm{C}$ compressor lubricant entrapment;

- compromises between performances, efficiency and battery ageing;

- condensation management.

\subsubsection{Decision Process among Thermal Management Technologies Porffolio}

The possible cooling methods already mentioned above (see Sect. 1.1.2.2 and introduction) have to be investigated, considered individually or in combination with each other, taking into account the following main structuring parameters:

- cooling performances and energetic balance;

- vehicle performances and life situations;

- weight and costs;

- layout, packaging and assembling;

- cabin thermal comfort and acoustics;

- quality and safety;

- aftersales.

In the following considerations, the temperature of the LV battery is assumed to be managed by refrigerant direct cooling, as illustrated in Section 1.3.2. However, other cooling methods are also investigated.

\section{BATTERY THERMAL MANAGEMENT SIMULATION MODEL AND CALCULATIONS}

\subsection{Battery Thermal Management Simulation Model}

A Matlab/Simulink LV battery simulation model has been built and implemented in a powertrain system platform where all powertrain components (ICE, electric motors, inverters, gear boxes, etc.) were previously developed and validated. The battery simulation model requires both electrical and thermal models, as illustrated in Appendix 3 in blue and red respectively. The battery simulation model is divided into different modules that are finally linked together: SOC, internal resistance, thermal losses, cell temperature, ageing factor, battery management restrictions for battery protection, etc.

The battery model is then coupled to the vehicle $\mathrm{A} / \mathrm{C}$ circuit model for co-simulation. The battery model provides thermal losses, cooler pressure drop and expansion valve setting as inputs to the $\mathrm{A} / \mathrm{C}$ circuit model which answers with inlet refrigerant temperature and pressure and the electric power required by cooling components.

\subsection{Battery Thermal Management Simulation Calculations}

Below are introduced some calculations examples, which illustrate the main uses of the battery simulation model. Two kinds of calculations are shown: firstly use profiles considering dimensioning of the thermal system in severe use-cases and secondly, powertrain energetic balance dimensioning use profiles.

\subsubsection{Thermal Dimensioning Profiles}

For each of the following use case (Fig. 1, 2), boundary conditions are:

- start SOC = SOC_max (for example 90\%);

- the refrigerant temperature is set to a constant value, to simplify calculations: $5^{\circ} \mathrm{C}$;

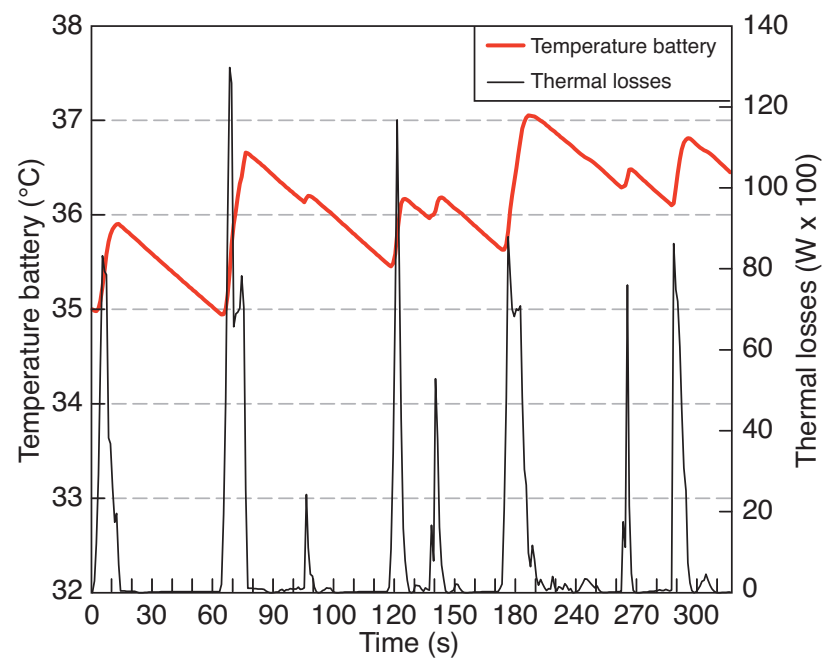

Figure 1

Evolution of the temperature of the battery on a urban sporty pure electric driving profile. 


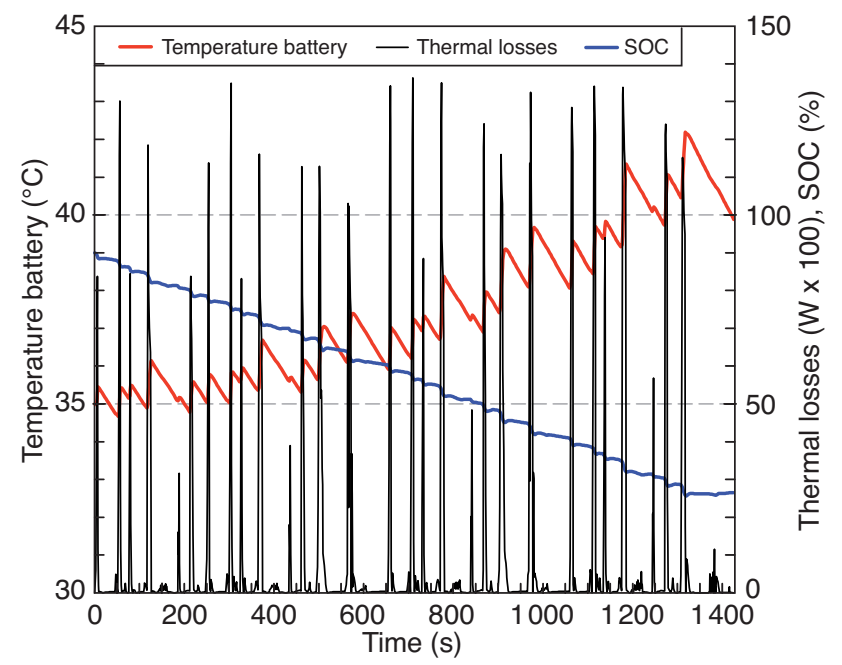

Figure 2

Evolution of the temperature of the battery on a urban pure electric driving profile.

- the initial battery temperature and the ambient temperature are equal to $35^{\circ} \mathrm{C}$;

- battery cooling starts as soon as the battery temperature reaches and is above $32^{\circ} \mathrm{C}$ and battery cooling stops as soon as the battery temperature reaches $28^{\circ} \mathrm{C}$.

The goal is here to validate that the battery thermal targets, for each use profile, are fulfilled, considering particular severity and occurrence of each use profile.

The dimensioning of the whole thermal system is acceptable regarding the different thermal parameters involved (cell maximal temperature, occurrence of use profiles, thermal gradients inside a single cell, between cells and at the surface of the battery cooler, etc.) and the ability of the whole thermal system to cool the battery is demonstrated.

\subsubsection{Energetic Balance Dimensioning Profiles}

For each of the following use cases (Fig. 3, 4), boundary conditions are:

- start SOC: same than above;

- the refrigerant temperature is the same than above;

- the initial battery temperature and the ambient temperature are respectively equal to $25^{\circ} \mathrm{C}$ (Fig. 3) and $17^{\circ} \mathrm{C}$ (Fig. 4);

- battery cooling starts and stops at the same temperatures than above.

The goal of this kind of simulations is to check local and global thermal losses and whether the battery needs to be cooled or not and if so, how many electric power is required by low and extra-low? voltages systems to do so.

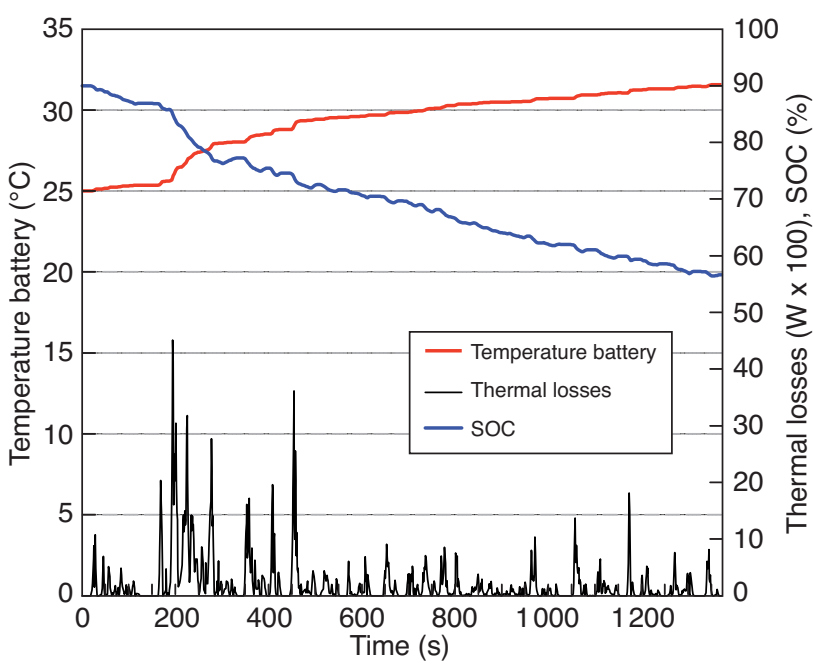

Figure 3

Evolution of the temperature of the battery on a single Federal Test Procedure (FTP) cycle.

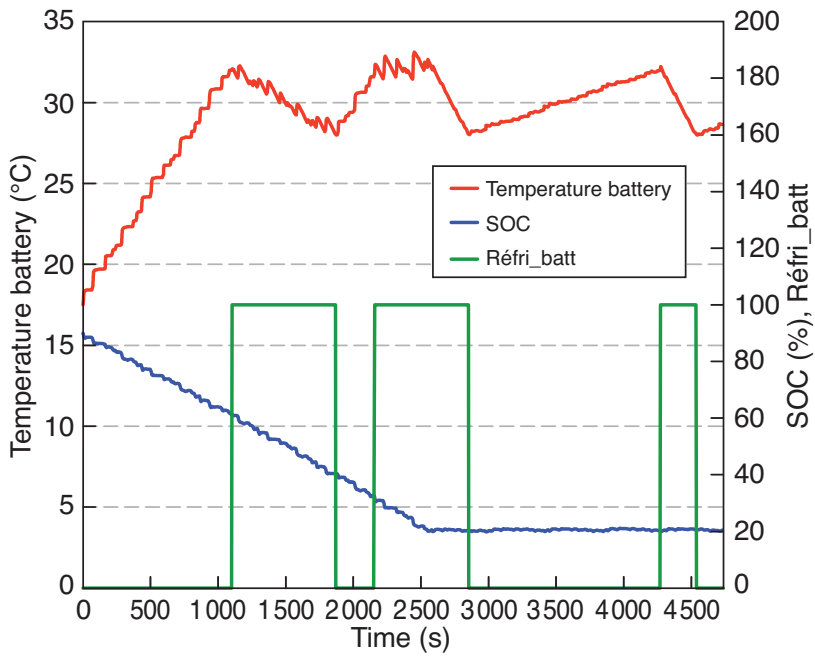

Figure 4

Evolution of the temperature of the battery on a kept moving urban traffic, quiet pure electric driving profile.

\section{STRATEGIES FOR IMPROVING VEHICLE EFFICIENCY AND BATTERY LIFETIME}

\subsection{Performances at Cold Temperatures}

\subsubsection{Context}

As already stated in the introduction and in the first section of this paper, battery performances are dramatically reduced at cold cell temperatures (in comparison with performances available inside the ideal temperature range of the battery), 
which result in reduced available useful energy and electric power. As a consequence, at cold cell temperatures, the electrical current really supplied (in discharge mode) or accepted (in charge mode) by the battery can be much lower than the current required or expected by the powertrain management system, which result in reduced electric drive autonomy or electric performances and, in case of a HEV, might cause the ICE to start. That's why active battery heating has been studied (so called "active" battery heating, in comparison with "passive" battery warm-up by Joule heating).

\subsubsection{Active Battery Heating}

Considering the assumption to manage the temperature of the battery by refrigerant direct cooling, a direct electric heating device, among heating technologies portfolio, has been investigated. This electric heating method is based on electric resistances or Positive Temperature Coefficient (PTC) heaters, fitted in direct thermal contact with cells. However, other heating methods are also investigated. Such a direct electric heating device has been chosen for its double heating effect:

- the battery auto-warms up (by Joule heating) quicker by supplying the additional electric power required by the electric heating system, etc.;

- ... which, of course, in return heats the battery up.

The maximal electric power involved in the direct electric heating device has been fixed to a value of $1000 \mathrm{~W}$ so that:

- the maximal heating thermal power is always lower than the cooling thermal power that can be provided by the cooling system in case of electric heating system failure;

- the maximal electric power is not too high in order not to dedicate too much electric power to heat the battery up, rather than propelling the car and not to exceed the total electric power available from the battery, otherwise it would lead to a worse energetic balance (and cause the ICE to start in case of a PHEV) and cause all the benefits of an active battery heating to be then lost.

Figures 5 and 6 below show, with and without operation of a $1 \mathrm{~kW}$-PTC heater, the evolution of the temperature of the battery, its benefits on the available battery electric power and its impact on the SOC evolution, on two different use cases: the first one (Fig. 5) on a hybrid mode, starting from a battery initial temperature of $-20^{\circ} \mathrm{C}$ at a constant ambient temperature of $-20^{\circ} \mathrm{C}$ and the other one (Fig. 6 ) on a pure electric mode, starting from a battery initial temperature of $-5^{\circ} \mathrm{C}$ at a constant ambient temperature of $-5^{\circ} \mathrm{C}$. Note that the PTC heater is disengaged in each case, as soon as the temperature of the battery reaches $10^{\circ} \mathrm{C}$, because it is there assumed and verified that the available electric power provided by the battery is then sufficient and because the Joule heating effect alone is also sufficient then to warm the battery up.

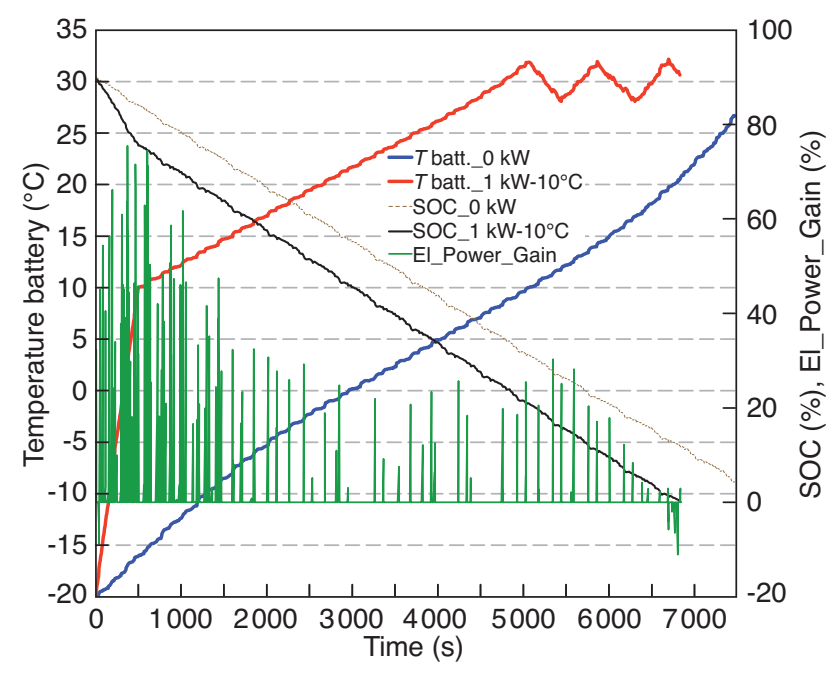

Figure 5

Hybrid use profile (start at $-20^{\circ} \mathrm{C}$ ), with and without $1 \mathrm{~kW}$ PTC heater operation.

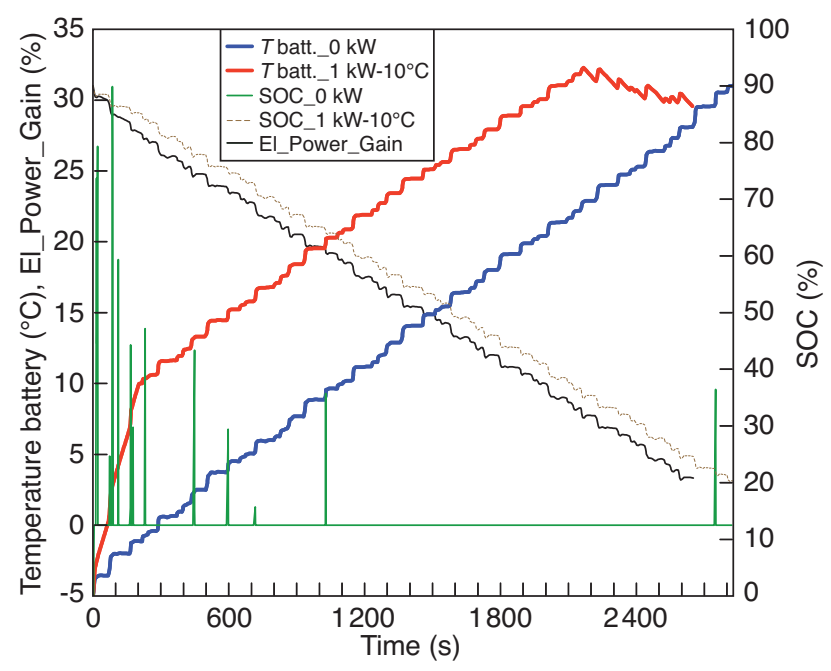

Figure 6

Pure electric use profile (start at $-5^{\circ} \mathrm{C}$ ), with and without $1 \mathrm{~kW}-\mathrm{PTC}$ heater operation.

Figure 5 shows that, on these conditions (cold ambient temperature: $-20^{\circ} \mathrm{C}$ and hybrid mode), as long as the $1 \mathrm{~kW}$ PTC is in use (until the temperature of the battery reaches $10^{\circ} \mathrm{C}$ ), battery heating sharply accelerates its warm-up, which helps to provide up to $+70 \%$ to $+80 \%$ additional electric power (green curves). This is made at the expense of a faster SOC decreasing (compare back continuous and dotted lines, linked to SOC evolution respectively with and without heater operation).

As illustrated in Figure 6, battery heating, on pure electric mode starting from $-5^{\circ} \mathrm{C}$, helps here the battery to provide 
up to $+20 \%$ to $+30 \%$ additional electric power at the expense of a faster SOC decreasing (as long as the $1 \mathrm{~kW}-\mathrm{PTC}$ is in use, i.e. until the temperature of the battery reaches $10^{\circ} \mathrm{C}$ ), even if ICE starting is delayed on pure electric driving cycles by cold conditions thanks to the additional electric power available from the battery due to its faster warm up.

\subsection{Battery Thermal Conditioning: Pre-Conditioning and Post-Cooling}

\subsubsection{Context}

As already stated in the introduction and in the first section of this paper, one of the main dimensioning criteria for battery lifetime is its average temperature, in every life-situation and especially during storage. Indeed, even if the temperature of the battery is actively managed during every customer use case in order to keep it in its optimal temperature range, a special attention has to be paid to the temperature of the battery in storage phases (parking, garage, etc.) as storage phases may represent up to $80-85 \%$ of the whole vehicle life expectance. As a consequence, a thermal management strategy dealing with battery thermal conditioning (pre-conditioning and postcooling) can play a key role.

\subsubsection{Plugged-in Battery Thermal Pre-Conditioning Benefits}

As an example, among several battery thermal conditioning strategies, plugged-in battery thermal pre-conditioning has been investigated on stand alone cycles and has revealed some slight benefits in cooling electric consumption and in pure electric driving range.

Are shown, in Figures 7 and 8 below, the benefits revealed during a sequence made of the succession of the following phases:

- initial temperature of the battery and ambient temperature (constant): $30^{\circ} \mathrm{C}$;

- the refrigerant temperature is set to a constant value: $5^{\circ} \mathrm{C}$;

- start SOC = SOC_max (for example 90\%);

- 3 pure electric urban driving cycles in a row, during which, for Figure 7, battery cooling starts as soon as the battery temperature reaches and is above $32^{\circ} \mathrm{C}$ and battery cooling stops as soon as the battery temperature reaches $30^{\circ} \mathrm{C}$ (respectively $35^{\circ} \mathrm{C}$ and $33^{\circ} \mathrm{C}$ for Fig. 8);

- then:

- in case of Figure 7, no thermal pre-conditioning, so due to its large thermal inertia and to the ambient temperature, the temperature of the battery keeps its value reached at the end of the pure electric driving phase;

- in case of Figure 8, active thermal pre-conditioning from the grid until the battery reaches a lower value (here, for example: $15^{\circ} \mathrm{C}$ ). The energy supplied by the grid is here (ambient temperature: $30^{\circ} \mathrm{C}$ ) about $410 \mathrm{Wh}$;

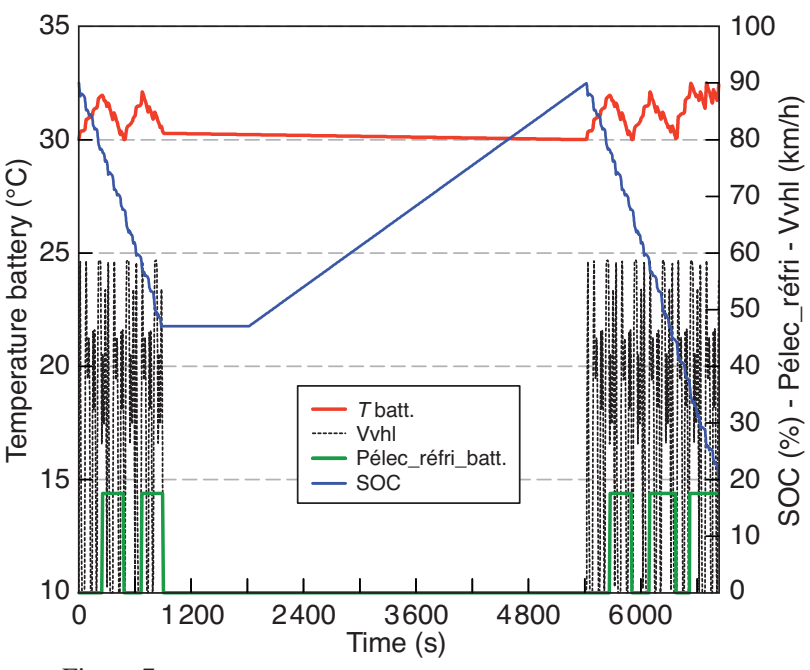

Figure 7

Sequence explained above, with $32 / 30^{\circ} \mathrm{C}$ battery temperature control and with no battery thermal pre-conditioning.

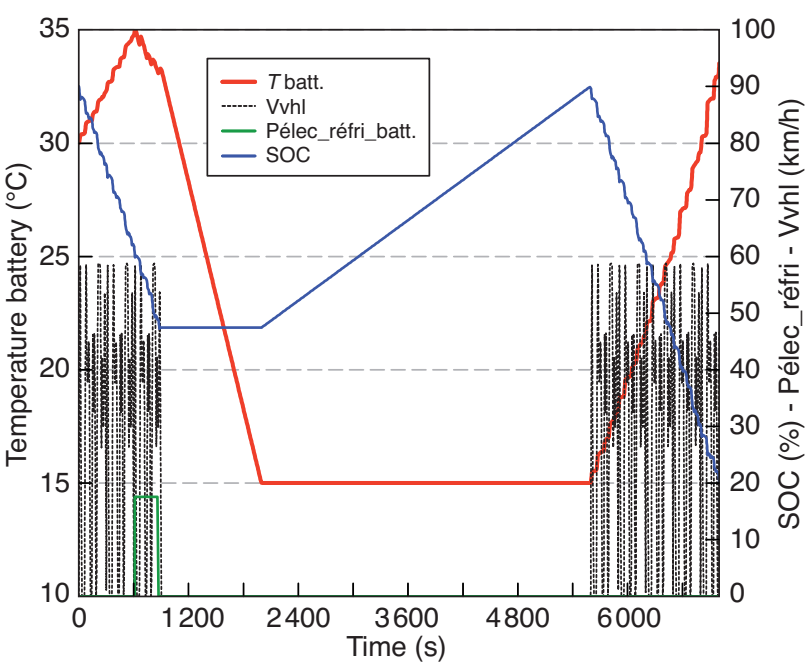

Figure 8

Sequence explained above, with $35 / 33^{\circ} \mathrm{C}$ battery temperature control and with battery thermal pre-conditioning at $15^{\circ} \mathrm{C}$.

- and then battery $3 \mathrm{~kW}$-charging from the grid, from the $\mathrm{SOC}$ reached at the end of the pure electric driving phase to the SOC_max value;

- finally, at the end of the charging: pure electric urban driving cycles in a row until full discharge of the battery (final SOC $=$ SOC_min).

Benefits are the following:

- thermal pre-conditioning alone allows a $133 \mathrm{~kJ}$ economy inside the battery on the second driving phase of the sequence (after the plug-in charging from the grid) because no battery cooling is then involved; 
- $35 / 33^{\circ} \mathrm{C}$ thermal regulation allows an additional $45 \mathrm{~kJ}$ economy (battery cooling starts later on the driving phases, with for example only one cooling cycle on the first driving phase, instead of two in case of $32 / 30^{\circ} \mathrm{C}$ thermal regulation);

- the total gain in pure electric driving range is between 200 and $300 \mathrm{~m}$ on this stand alone sequence, which corresponds to around $2 \%-3 \%$ of the total range of the vehicle on this driving profile;

- as shown by Figure 8, this thermal pre-conditioning strategy allows to dedicate, during battery warm-up, the whole refrigerant cooling power to cabin $\mathrm{A} / \mathrm{C}$ system for cabin thermal comfort convergence, since there is no more need to cool down the battery.

In this example, impacts on battery lifetime and additional electric consumption from the grid have not been considered.

\subsubsection{Global Thermal Conditioning Strategy on Battery Lifetime}

A one-week (working days and week-end) sequence has been defined by combination of pure electric and hybrid driving (town, road, highway) and storage phases (including especially plug-in recharges, parking phases when vehicle is not plugged, overnight parking). The vehicle is considered to be plugged to the grid as soon as possible, since PHEV and EV owners are encouraged to do so, provided that the electric power from the grid (interfaces, supply, etc.) is available. The sequence has been simulated in:

- winter: ambient temperature from $-20^{\circ} \mathrm{C}$ to $+10^{\circ} \mathrm{C}$ and active cabin thermal comfort in both warm-up and steady states of the cabin and the ICE, in heating, demisting and defrosting modes;

- summer: ambient temperature from $+15^{\circ} \mathrm{C}$ to $+40^{\circ} \mathrm{C}$ and active cabin thermal comfort in warm-up and steady states, in cooling mode;

- and spring/autumn: ambient temperature from $+10^{\circ} \mathrm{C}$ to $+25^{\circ} \mathrm{C}$ and active cabin thermal comfort in warm-up and steady states, in heating, demisting and cooling modes.

On this sequence, on the different weather conditions, battery behaviour has been simulated and especially the evolution of its temperature has been evaluated with and without operation of the global thermal conditioning strategy presented hereafter:

- plugged-in battery thermal pre-conditioning: as soon as the vehicle is connected to the grid, depending on the temperature of the battery and the ambient temperature, the battery is cooled down until its temperature is equal to or lower than a given threshold;

- not plugged-in battery post-cooling: after a driving sequence, depending on the temperature of the battery and the ambient temperature, the battery is cooled down until the first of the following conditions is verified: the temperature of the battery is equal to or lower than a given threshold, or the battery cooling time exceeds a given maximal duration, this threshold being different from the one associated to plugged-in thermal pre-conditioning operation.

Although the vehicle is plugged to the grid as soon as it is possible to do so, the phases during which electric power is actually consumed from the grid represent however only a very little part of the whole "vehicle plugged" duration. The vehicle is supposed to be plugged $90 \%$ of the whole duration of the non-driving phases and the calculations show that consumption of electric power from the grid occurs (because it is required by the thermal management strategy) only during $6 \%$ of the whole vehicle plugged duration.

Appendixes 4 and 5 hereafter demonstrate the positive impacts of this battery thermal conditioning strategy on its temperature. Appendix 4 shows the cumulative time and the percentage of time (regarding the whole sequence duration) spent by the battery inside each temperature range, with and without thermal conditioning strategy. With thermal conditioning strategy, the battery temperature distribution is better oriented, spending, as far as battery ageing is regarded, more time in low temperature values and less time on highest temperature values. Consequently and in addition, as shown by Appendix 5, the battery annual average temperature is lowered by more than $3^{\circ} \mathrm{C}$ (with especially a gain of more than $6^{\circ} \mathrm{C}$ in summer) thanks to this battery thermal conditioning strategy. Appendix 5 also presents the average daily extraconsumption, from the grid due to plugging-in phases, that results from this thermal management strategy, with an annual average daily electric extra-consumption of $238 \mathrm{Wh}$.

Although influence on battery lifetime itself is still in progress, benefits are expected as this thermal conditioning strategy contributes to decrease battery average temperature and improve temperature distribution.

\subsection{Optimization Process between Vehicle Performances and Battery Lifetime}

\subsubsection{Mainspring}

The strategy aims at adjusting battery operating conditions influencing its ageing (performance level required, use range, thermal management) in order to optimize vehicle performances (consumption, range, cabin thermal comfort, etc.) in compromise with battery lifetime.

Customer use-cases are considered as boundary conditions, especially characterized by ambient temperature (climate, storage conditions, etc.), number of plug-in recharges per day, driving mode (pure electric, hybrid), area (city, road, highway, etc.) and type (quiet, sporty, etc.), etc.

The main optimization directions are:

- to release battery operating conditions of a so-called non-severe customer, in order to significantly improve 
allowed performances, even if battery ageing becomes then equivalent to that of a more severe customer;

- to optimize battery operating conditions of a given customer to improve performances at same lifetime (example: boost of battery cooling for State of Function (SOF) range enlargement).

\subsubsection{Damaging Factor}

To do so, a damaging factor has been defined and is, in real time, evaluated considering battery operating conditions and compared to a maximal target. This damaging factor aims to guarantee as much as possible the battery lifetime on the whole vehicle lifetime for every customer. The main parameters taken into account are absorbed and restored energy per SOC range, time per battery temperature range (both driving and storage phases included) and per current range, total ageing and mileage, etc. This damaging factor can have an influence on the Depth of Discharge (DOD), SOF, available electric power adjustment and also battery thermal management: battery regulation temperature adjustment, thermal conditioning, etc.

In case of a non-severe customer with low requests (low useful SOF, nominal battery cooling, nominal ambient temperature, short pure electric drives, quiet driving, etc.), the strategy can allow, for example, increased useful SOF or moderate battery cooling to improve vehicle performances such as consumption, pure electric drive range, etc.

A so-called severe customer is characterized by demanding operating conditions such as sporty driving, high ambient temperature, frequent pure electric drives, several plug-in recharges per day, etc. and as a consequence with a low useful SOF and a maximal battery cooling in order to preserve it from ageing, even if not sufficient enough. In such a case, the strategy can switch the battery operating point, for example by reducing DOD, lowering battery temperature regulation if possible, decreasing available electric power, so as battery lifetime is improved through vehicle performances optimization and compromises.

The benefits of such a strategy that can already be foreseen are:

- battery lifetime;
- in use improvement of fuel consumption and pure electric drive range;

- performances (fuel consumption, pure electric drive range, available electric power, etc.) robustness and everlastingness.

\section{CONCLUSION}

Thermal management plays a key role for LV battery performances over lifetime. The related thermal system has to be developed in accordance with vehicle and powertrain requirements, architecture and design of the battery pack, environmental constraints, costs, weight, etc.

Battery thermo-electric and thermal management simulation models have been developed and linked for co-simulation with vehicle models.

Promising thermal management strategies have been identified, evaluated and validated, for improving vehicle efficiency and performances in compromise with battery lifetime.

To go further, simulation models have to be deeper developed and investigated, especially regarding battery ageing (sensitivity of operating parameters to ageing). Another next step is also to assess heat pump potentials for cabin thermal comfort, battery thermal management and vehicle efficiency.

\section{REFERENCES}

1 Zhang X. (2009) Multiscale Modeling of Li-Ion Cells: Mechanics, Heat Generation and Electrochemical Kinetics, PhD Thesis, University of Michigan.

2 Srinivasan V., Wang C.Y. (2003) Analysis of Electrochemical and Thermal Behavior of Li-Ion Cells, J. Electrochem. Soc. 150, 1, A98-A106.

3 Thomas K.E., Newman J. (2003) Thermal Modeling of Porous Insertion Electrodes, J. Electrochem. Soc. 150, 2, A176-A192.

4 Zhang X., Sastry A.M., Shyy W. (2008) Intercalation-Induced Stress and Heat Generation within Single Lithium-Ion Battery Cathode Particles, J. Electrochem. Soc. 155, A542-A552.

5 Chen S.C., Wan C.C., Wang Y.Y. (2005) Thermal Analysis of Li-ion Batteries, J. Power Sources 140, 111-124.

Final manuscript received in May 2012 Published online in March 2013 


\section{APPENDIXES}

\section{Appendix 1}

Diagram of the electric power available as a function of average battery temperature.

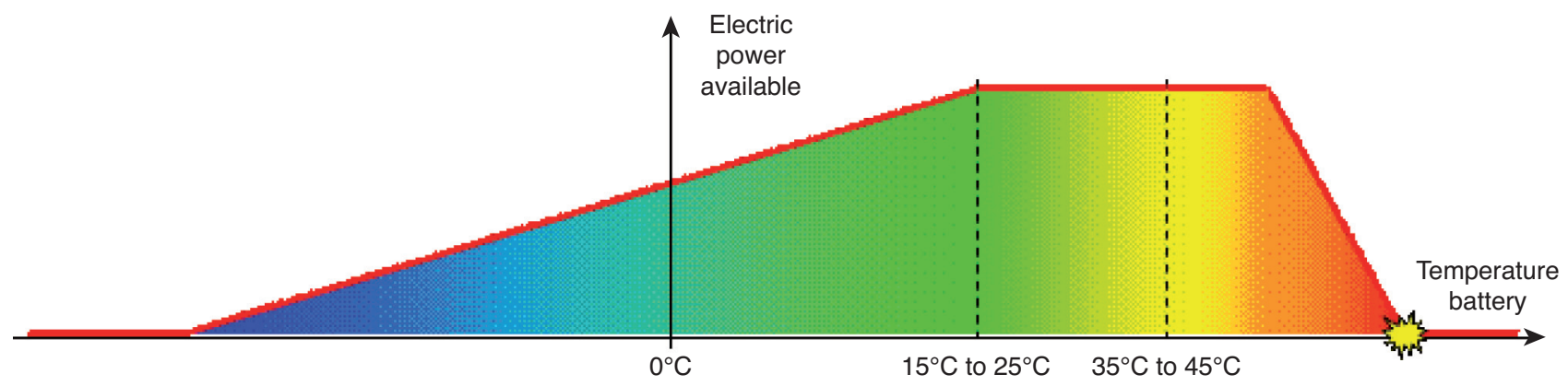

\section{Appendix 2}

Scheme of an architecture for LV battery direct cooling through refrigerant.

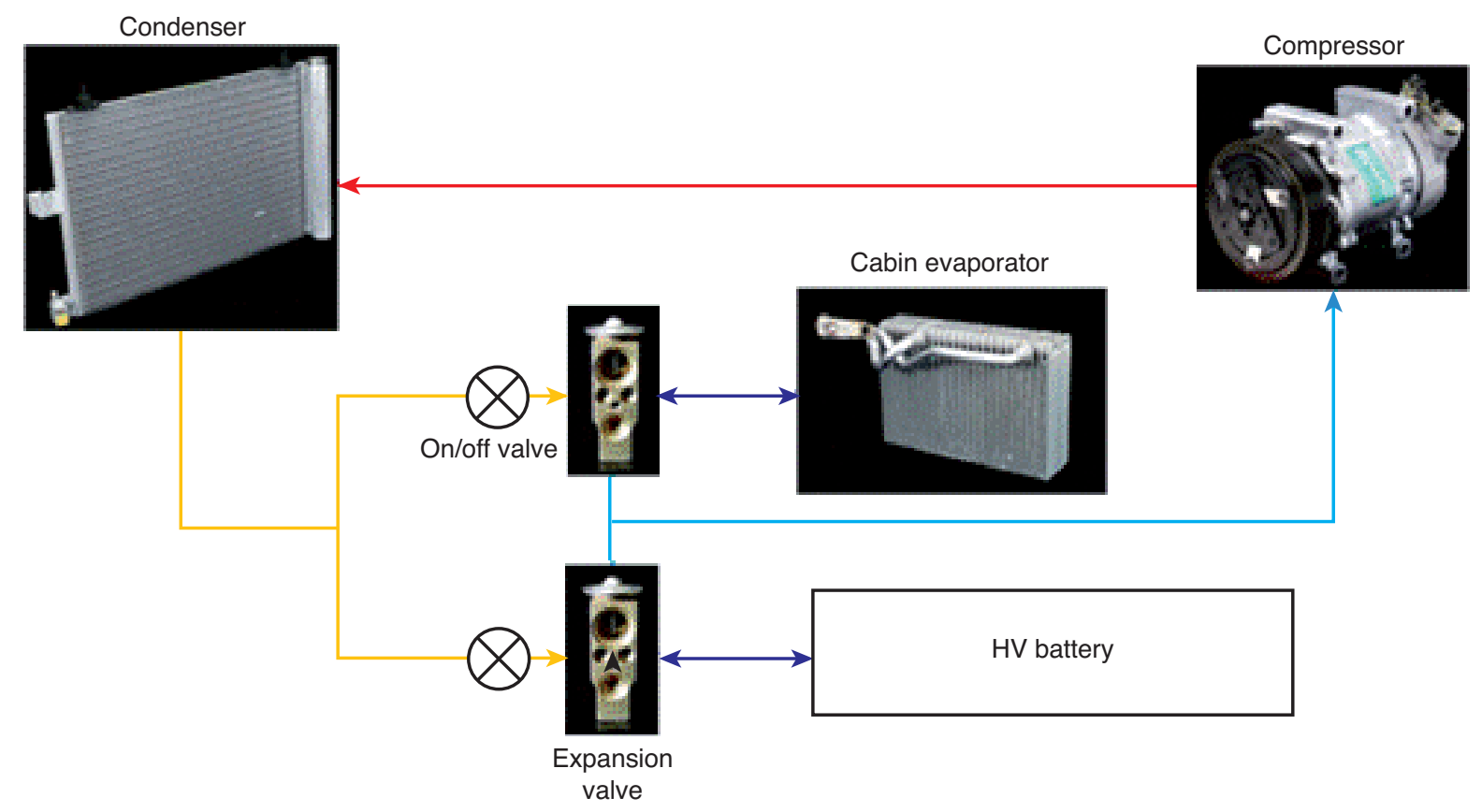




\section{Appendix 3}

Battery thermo-electric simulation model.

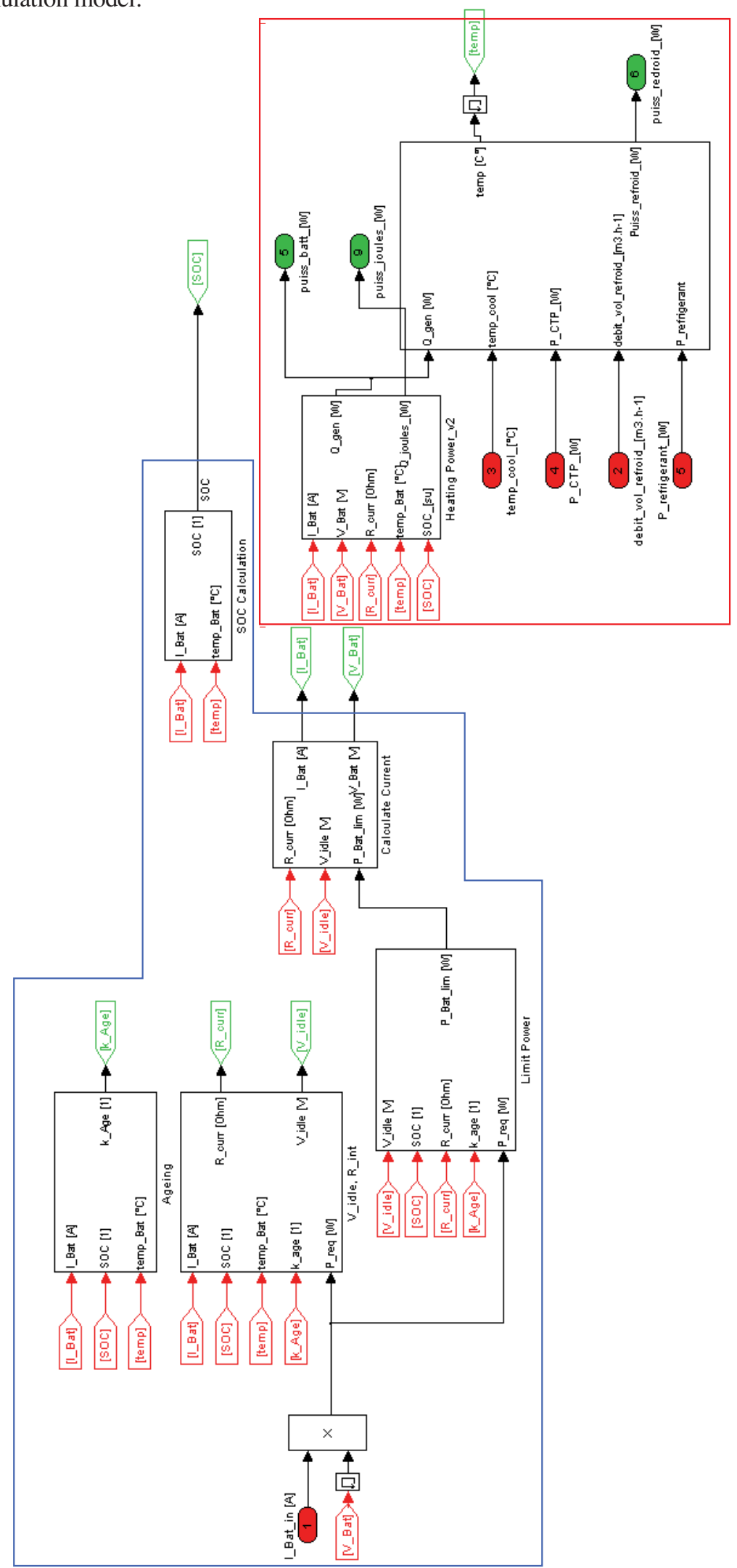




\section{Appendix 4}

Impacts of a thermal conditioning strategy on the temperature distribution of a battery.
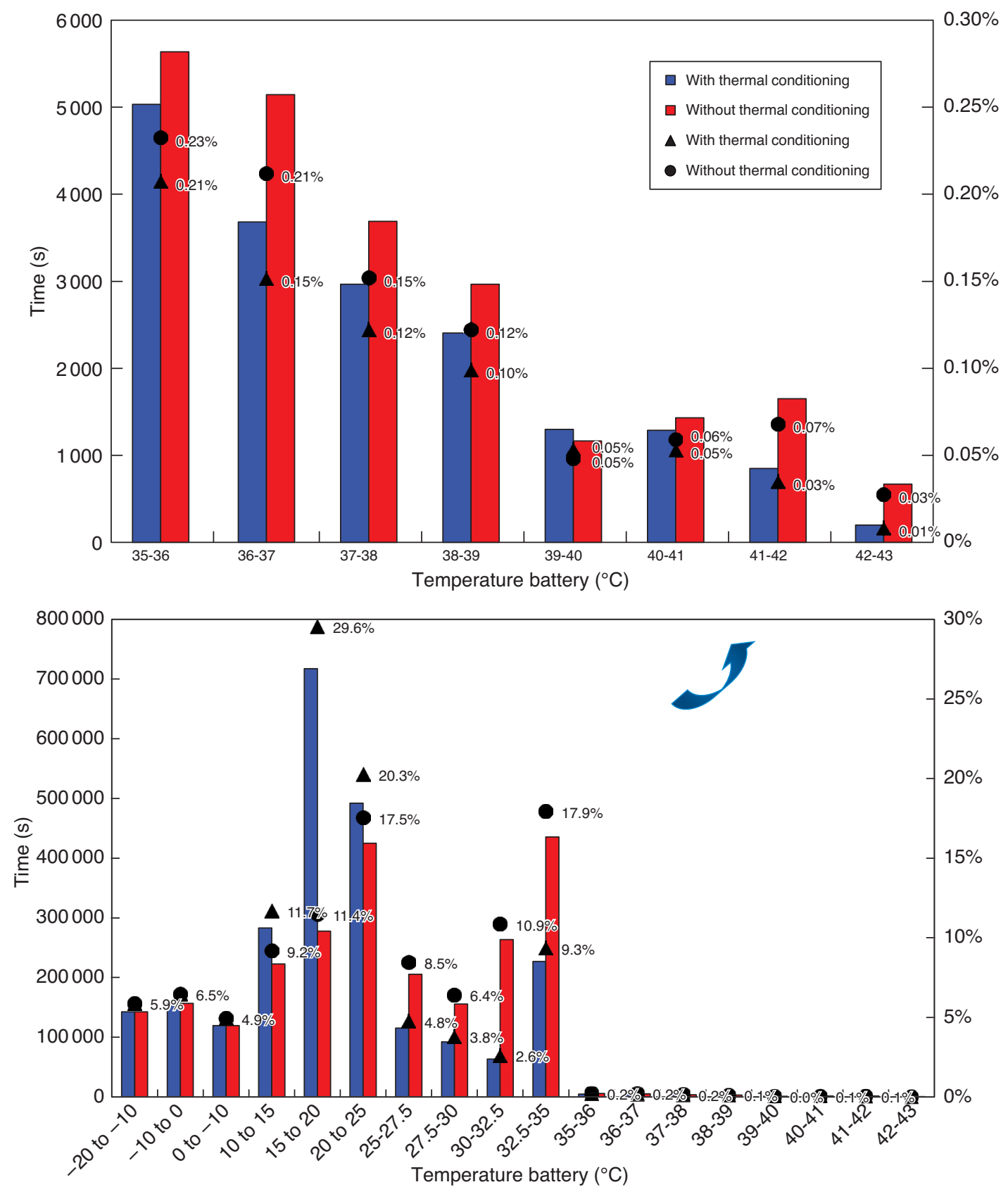


\section{Appendix 5}

Impacts of a thermal conditioning strategy on the average temperature of a battery.

\begin{tabular}{c|c|c|c|c}
\hline & Summer & $\begin{array}{c}\text { Spring } \\
\text { Autumn }\end{array}$ & Winter & Annual \\
\hline Without thermal conditioning strategy & $30.5^{\circ} \mathrm{C}$ & $23.2^{\circ} \mathrm{C}$ & $3.2^{\circ} \mathrm{C}$ & $20^{\circ} \mathrm{C}$ \\
\hline With thermal conditioning strategy & $24.2^{\circ} \mathrm{C}$ & $20^{\circ} \mathrm{C}$ & $3.2^{\circ} \mathrm{C}$ & $16.8^{\circ} \mathrm{C}$ \\
\hline Gain & $6.3^{\circ} \mathrm{C}$ & $3.2^{\circ} \mathrm{C}$ & - & $3.2^{\circ} \mathrm{C}$ \\
\hline Average daily extra-consumption from the grid due to plugging-in phases & $460 \mathrm{Wh}$ & $245 \mathrm{Wh}$ & 0 & $238 \mathrm{Wh}$ \\
\hline
\end{tabular}

